\title{
Pengaruh Vitamin C dan E terhadap Histologi Tuba Fallopii pada Tikus yang Dipapar MSG
}

\section{The Effect of Vitamin C and E on the Fallopian Tubes Histology of MSG-exposed Rats}

\author{
Riza Umami $i^{1}$ Pande Made $D^{2}$, Sri Winarsih ${ }^{3}$ \\ ${ }^{1}$ Program Studi Magister Kebidanan Universitas Brawijaya Malang \\ 2 Laboratorium Obstetri dan Ginekologi Rumah Sakit Umum Daerah Dr. Saiful Anwar Malang \\ ${ }^{3}$ Laboratorium Mikrobiologi Fakultas Kedokteran Universitas Brawijaya Malang
}

\begin{abstract}
ABSTRAK
Monosodium glutamat (MSG) adalah garam natrium dari asam glutamat yang digunakan sebagai penyedap rasa. MSG berpengaruh pada motilitas tuba yaitu pada lapisan otot polos dan jumlah sel epitel sekretorik tuba fallopii. Penelitian ini bertujuan untuk mengetahui pengaruh kombinasi vitamin $\mathrm{C}$ dan $\mathrm{E}$ terhadap jumlah sel epitel sekretorik dan tebal lapisan otot polos tuba fallopii pada tikus yang dipapar MSG selama 42 hari. Desain penelitian yang digunakan adalah eksperimental laboratorik dengan menggunakan 25 ekor tikus betina dewasa yang dibagi menjadi 5 kelompok yaitu K(-) adalah kontrol negatif; K(+) MSG 0,7mg/g BB; PI mendapat MSG 0,7mg/gBB +vitamin C 0,2mg/gBB+vitamin E 0,04 IU/gBB; PII mendapat MSG 0,7mg/gBB +vitamin C 0,4mg/gBB+vitamin E 0,04 IU/gBB; PIII mendapat MSG 0,7mg/gBB+vitamin C $0,8 \mathrm{mg} / \mathrm{gBB}+\mathrm{vitamin}$ E 0,04 IU/gBB. Pada hari ke-43 tikus yang diterminasi adalah pada fase proestrus lalu dilakukan pemeriksaan histopatologi tuba fallopii dengan pengecatan HE yang diamati dibawah mikroskop Dot Slide. Uji one way ANOVA menunjukkan hasil bahwa kombinasi vitamin $\mathrm{C}$ dan $\mathrm{E}$ dapat meningkatkan jumlah sel epitel sekretorik dan tebal lapisan otot polos (masing-masing $p=0,000$ dan $p=0,042$ ). Diduga hal tersebut disebabkan oleh menurunnya kadar estrogen pada siklus reproduksi. Kesimpulan dalam penelitian ini adalah kombinasi dosis vitamin $\mathrm{C}$ dan vitamin $\mathrm{E}$ meningkatkan jumlah sel epitel sekretorik dan tebal lapisan otot polos tuba fallopii tikus yang dipapar MSG, meskipun tidak bermakna antar kelompok dosis.
\end{abstract}

Kata Kunci: Jumlah sel epitel sekretorik, tebal lapisan otot polos, tuba fallopii, MSG, vitamin C, vitamin E

\begin{abstract}
Monosodium glutamate (MSG) is sodium salt from glutamate acid used as flavor enhancer. MSG affects tube motility on smooth muscle layers and the number offallopian tube secretory epithelial cells. This research aims to determine the effect of vitamin C and E combination on the number of secretory epithelial cells and smooth muscle thickness of fallopian tubes in rats exposed to MSG for 42 days. The research design is an experimental post-test control group design using 25 adult female rats divided into 5 groups, namely $K(-)$ is the negative control; $K(+)$ MSG $0,7 \mathrm{mg} / \mathrm{g} \mathrm{BW;} \mathrm{PI} \mathrm{received} \mathrm{MSG} \mathrm{0,7} \mathrm{mg/g}$ $B W+$ Vitamin $C 0,2 \mathrm{mg} / \mathrm{g}+$ Vitamin $E 0,04 \mathrm{IU} / \mathrm{g} B W ; P I I$ received MSG 0,7mg/g BW + vitamin C 0,4mg/g BW + vitamin E 0,04 $I U / g$ BW; PIII received MSG 0,7mg/g BW + vitamin C $0,8 \mathrm{mg} / \mathrm{g} B W+$ vitamin E 0,04 IU/g BW. On the $43^{\text {rd }}$ day, the rats were terminated in proestrus phase and their fallopian tube hystopathologies were examined with HE staining under Dot Slide microscope. One way ANOVA test results show that the combination of vitamin $C$ and $E$ tend to increase the number of secretory epithelial cells and smooth muscle thickness ( $p=0,000$ and $p=0,042$ respectively), presumably due to the decreasing of estrogen secretion on reproduction cycle. In short, the dosage combination of vitamin $C$ and $E$ tends to increase the amount of secretory epithelial cells and smooth muscle thickness fallopian tubes of MSG-exposed mice although significantly indistinctive.
\end{abstract}

Keywords: Fallopian tube, MSG, number of secretory epithelial cells, smooth muscle thickness, vitamin C, vitamin E

Jurnal Kedokteran Brawijaya, Vol. 28, No. 2, Agustus 2014; Korespondensi: Riza Umami. Program Studi Magister Kebidanan Universitas Brawijaya Malang, Jl.Veteran Malang65145 Tel.(0341)569117Email: rizaumami1984@yahoo.co.id 


\section{PENDAHULUAN}

Monosodium glutamat atau yang lazim disingkat MSG sering dijadikan penambah rasa pada makanan karena memiliki rasa yang unik selain asin, asam, manis dan pahit yang disebut dengan rasa umami. Pengolahan sintetis dari glutamat menghasilkan suatu bentuk yang bersifat exitoxin, jika mengkonsumsinya secara berlebih maka akan menyebabkan konsentrasi glutamat dalam darah meningkat yang dapat berubah menjadi radikal Hidroksil $\left(\mathrm{OH}^{-}\right)$dan menginduksi terjadinya stres oksidatif (1). MSG juga secara nyata berpengaruh pada kerusakan hipotalamus dan hipofise dalam sekresi hormon yang berfungsi untuk perkembangan gonad pria dan wanita (2).

Beberapa penelitian menunjukkan bahwa pemberian MSG 0,7mg/gBB selama 30 hari menyebabkan penurunan jumlah korpus luteum, peningkatan jumlah folikel sekunder dan tersier, dan kerusakan pada sel granulosa pada tikus (3). Reactive oxygen species (ROS) di tuba fallopii dapat menyebabkan efek apoptosis sel yang memicu terjadinya kegagalan implantasi, ancaman kehamilan ektopik, endometriosis, hydrosalpinx, dan polikistik ovarium pada embrio (4). Pemberian MSG sebesar $0,04 \mathrm{mg} / \mathrm{kgBB}$ dan $0,08 \mathrm{mg} / \mathrm{kgBB}$ selama 40 hari dapat menyebabkan hipertrofi sel dan lisis pembuluh darah pada lapisan muskuler tuba fallopii (5).

Tuba fallopii memiliki fungsi menangkap ovum saat ovulasi, lalu mengantarkan ovum untuk bertemu dengan sperma sampai terjadinya konsepsi. Fungsi tersebut dipengaruhi oleh otot polos, jumlah epitel bersilia dan epitel sekretorik (6). Sel sekretorik tuba yang berisi cairan nutritif banyak mengandung mukoproteins, elektrolit dan enzim yang diduga berasal dari transudasi selektif darah dan sekresi aktif dari lapisan epitel, cairan tersebut akan meningkat pada saat fase proestrus (7). Pemberian MSG secara umum mempengaruhi mekanisme kerja hipotalamus sehingga GnRH turun begitu juga FSH dan LH, yang berakibat juga pada keseimbangan estrogen dan progesteron. Sifat hormon estrogen merangsang pertumbuhan follikel ovarium dan meningkatkan gerak peristaltik pada otot polos untuk menggerakkan sel epitel tuba fallopi. Estrogen menurunkan sekresi FSH melalui umpan balik negatif (negative feed back). Di sisi lain pada sekresi LH, di satu sisi estrogen menghambat LH melalui umpan balik negatif, disisi lain juga meningkatkan sekresi LH melalui mekanisme umpan balik positif (8).

Antioksidan dibutuhkan untuk menetralisir ROS dalam tubuh yang sedang meningkat, salah satu contoh antioksidan adalah vitamin C dan vitamin $\mathrm{E}$. Vitamin C dapat membantu menetralisir ROS sebelum menyerang lipid dan vitamin E menghambat terjadinya peroksidasi lipid, jika kedua vitamin tersebut dikombinasikan maka dapat menangkal ROS dengan maksimal. Beberapa penelitian menyatakan bahwa pemberian kombinasi vitamin $C(0,2 \mathrm{mg} / \mathrm{gBB}, 0,4 \mathrm{mg} / \mathrm{gBB}, 0,8 \mathrm{mg} / \mathrm{gBB})$ dan $\mathrm{E}$ $(0,04 \mathrm{lU} / \mathrm{gBB})$ berpengaruh terhadap penurunan jumlah sel radang paru tikus yang dipapar asap rokok selama 10 minggu (9). Defisiensi vitamin E menyebabkan masalah pada lemahnya otot, degenerasi hasil konsepsi dan infertilitas (10). Berdasarkan uraian diatas, nampak bahwa ada pengaruh pemberian kombinasi vitamin $C$ dan vitamin E pada jumlah sel epitel sekretorik dan tebal lapisan otot polos tuba fallopii tikus yang dipapar MSG.

\section{METODE}

Penelitian ini dilakukan secara true eksperimental laboratorik dengan Rancangan Acak Lengkap (RAL) menggunakan post test dengan kelompok kontrol (Randomized Post Test Only Control Group Design) (11). Hewan coba yang digunakan adalah tikus putih (Rattus norvegicus) galur Wistar yang berjumlah 25 ekor yang telah sesuai dengan kriteria inklusi.

Tempat penelitian dilakukan di Laboratorium Farmakologi dan Laboratorium Patologi Anatomi Fakultas Kedokteran Universitas Brawijaya Malang pada Oktober-November 2013. Sebelum perlakuan, hewan coba telah dilakukan aklimatisasi untuk menyesuaikan dengan lingkungan yang baru selama 7 hari. Hewan coba dibagi menjadi 5 kelompok yaitu kelompok Kontrol (-) adalah tikus yang tidak diberikan apapun, Kontrol $(+)$ dipapar MSG $0,7 \mathrm{mg} / \mathrm{gBB}, \mathrm{PI}$ dipapar MSG 0,7mg/gBB+vitamin C $0,2 \mathrm{mg} / \mathrm{gBB}+$ vitamin E $0,04 \mathrm{IU} / \mathrm{gBB}$, PII dipapar MSG $0,7 \mathrm{mg} / \mathrm{gBB}+$ vitamin $\mathrm{C} 0,4 \mathrm{mg} / \mathrm{gBB}+$ vitamin $\mathrm{E} 0,04 \mathrm{IU} / \mathrm{gBB}$ dan PIII dipapar MSG 0,7mg/gBB+vitamin C 0,8mg/gBB+vitamin E 0,04 IU/gBB selama 42 hari personde.

MSG yang digunakan adalah L-glutamic acid monosodium salt hydrate 99\%, Merck Sigma Aldrich dengan dosis $0,7 \mathrm{mg} / \mathrm{gBB}$. Vitamin C Merck Sigma Chemical dengan dosis yaitu $0,2 \mathrm{mg} / \mathrm{gBB} ; 0,4 \mathrm{mg} / \mathrm{gBB}$ dan $0,8 \mathrm{mg} / \mathrm{gBB}$ yang dilarutkan dengan aquades $0,5 \mathrm{cc}$ dan Vitamin $\mathrm{E}$ (Natur-E) dengan dosis 0,04 IU/gBB yang dilarutkan dengan minyak wijen $0,5 c c$.

Swab vagina dilakukan pada hari ke-43, tikus diterminasi jika berada pada fase proestrus yang ditandai oleh banyaknya sel epitel yang memiliki inti, berbentuk bulat dan leukosit sedikit, sedangkan yang tidak sedang berada pada fase proestrus, ditunggu dan tetap mendapat perlakuan. Setelah tikus dibedah, organ tuba fallopii diambil untuk dilakukan pemeriksaan histopatologi pada jumlah sel epitel sekretorik dan tebal otot polos tuba fallopii tikus dengan metode pengecatan Hematoksilin dan Eosin potongan transversa.

Uji prasyarat dalam penelitian ini adalah uji normalitas data dengan menggunakan uji Shapiro-Wilk dan uji homogenitas dengan menggunakan uji Levene. Pengolahan data menggunakan metode one way ANOVA, hal tersebut bertujuan untuk menguji apakah ada perbedaan antara kelompok perlakuan yang diberikan MSG, kombinasi dosis Vitamin C dan Vitamin E terhadap jumlah sel epitel sekretorik dan tebal otot polos tuba fallopi dengan taraf kepercayaan 5\%. Jika syarat-syarat diatas terpenuhi, selanjutnya dilakukan uji parametrik (11).

\section{HASIL}

Hasil menunjukkan bahwa jumlah sel epitel skretorik tuba falopii terbanyak ditemukan pada perlakuan III $\quad(85,04 \pm$ $15,66)$ dan terendah pada kelompok kontrol negatif $(52,2 \pm$ 15,41). Peningkatan dosis vitamin C memberikan 
peningkatan jumlah sel epitel sekretorik. Uji one way ANOVA $(p=0,000)$ menunjukkan bahwa ada pengaruh yang signifikan pada pemberian kombinasi vitamin $\mathrm{C}$ dan $\mathrm{E}$ terhadap peningkatan jumlah sel epitel sekretorik tuba jika dibandingkan dengan $\mathrm{K}(+)$.

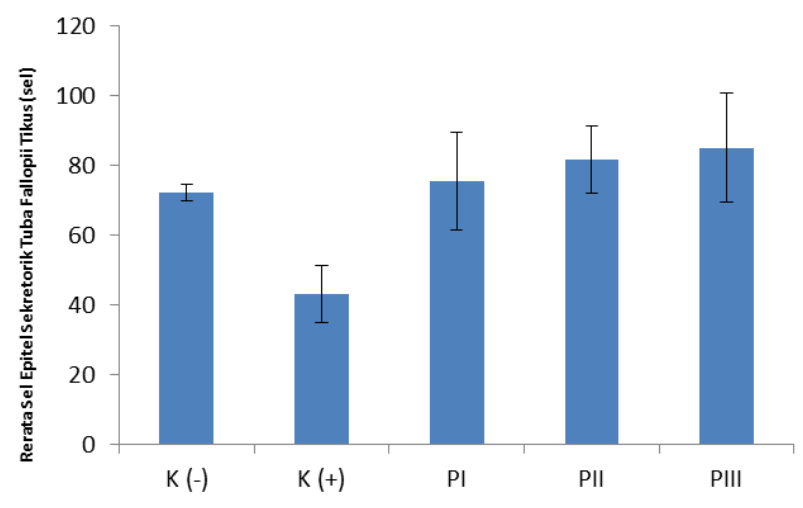

Gambar 1. Perbandingan rerata jumlah sel epitel sekretorik antar kelompok

Keterangan:

$\mathrm{K}(-) \quad$ : tidak mendapat MSG dan tidak mendapat kombinasi dosis vitamin $\mathrm{C}$ dan $\mathrm{E}$

$\mathrm{K}(+)$ : MSG $0,7 \mathrm{mg} / \mathrm{gBB}$ dan tidak mendapat kombinasi dosis vitamin C dan $\mathrm{E}$

PI : MSG 0,7 mg/gBB, vitamin C 0,2 mg/gBB, vitamin E 0,04 IU/gBB

PII : MSG 0,7 mg/gBB, vitamin C 0,4 mg/gBB, vitamin E 0,04 IU/gBB

PIII : MSG 0,7 mg/gBB, vitamin C 0,8 mg/gBB, vitamin E 0,04 IU/gBB

Untuk mengetahui lebih lanjut perbedaan antar perlakuan, dilakukan uji lanjut post hoc test dengan menggunakan uji LSD (Tabel 1). Uji LSD menunjukkan pemberian MSG menurunkan jumlah sel epitel sekretorik tuba falopii secara bermakna. Pemberian kombinasi vitamin C dan vitamin E meningkatkan jumlah sel epitel sekretorik secara bermakna bila dibandingkan kondisi saat diberi MSG. Peningkatan dosis Vitamin C meningkatkan jumlah sel epitel hingga lebih tinggi dari kondisi normal (kontrol negatif).

Tabel 1. Hasil uji LSD jumlah sel epitel sekretorik

\begin{tabular}{lccccc}
\hline Kelpk & $\mathbf{K}(-)$ & $\mathbf{K}(+)$ & PI & PII & PIII \\
\hline K(-) & & $0,274^{*}$ & $0,010^{*}$ & $0,002^{*}$ & $0,001^{*}$ \\
$\mathrm{~K}(+)$ & & & $0,001^{*}$ & $0,000^{*}$ & $0,000^{*}$ \\
$\mathrm{PI}$ & & & & $0,462^{*}$ & $0,256^{*}$ \\
$\mathrm{PII}$ & & & & & 0,680 \\
PIII & & & & & \\
\hline$p$-value $<0,05$ adalah bermakna & $\left({ }^{*}\right)$ & & &
\end{tabular}

Uji one way ANOVA $(p=0,042)$ menunjukkan bahwa terdapat pengaruh yang signifikan pada pemberian kombinasi vitamin $\mathrm{C}$ dan $\mathrm{E}$ berbagai dosis terhadap peningkatan tebal lapisan otot polos tuba fallopii jika dibandingkan dengan $\mathrm{K}(+)$.

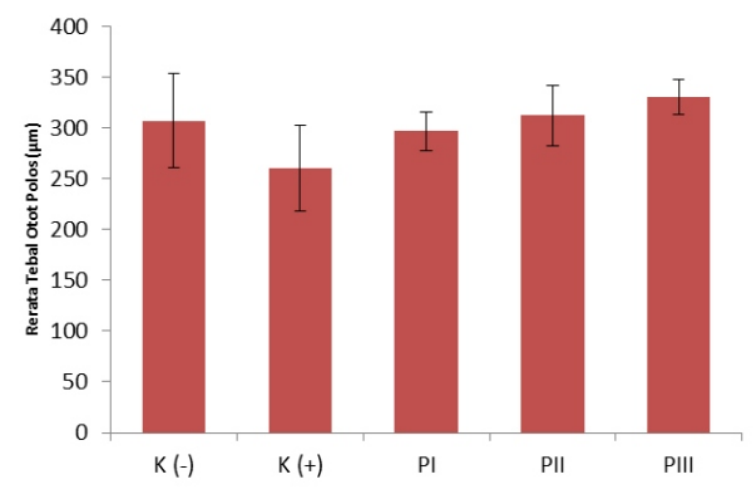

Gambar 2. Perbandingan rerata tebal lapisan otot polos tuba fallopii antar kelompok perlakuan

Keterangan:

K(-) : tidak mendapat MSG dan tidak mendapat kombinasi dosis vitamin $\mathrm{C}$ dan $\mathrm{E}$

$\mathrm{K}(+)$ : MSG 0,7 mg/gBB dan tidak mendapat kombinasi dosis vitamin C dan $\mathrm{E}$

PI : MSG 0,7 mg/gBB, vitamin C 0,2 mg/gBB, vitamin E 0,04 IU/gBB

PII : MSG 0,7 mg/gBB, vitamin C 0,4 mg/gBB, vitamin E 0,04 IU/gBB

PIII : MSG 0,7 mg/gBB, vitamin C 0,8 mg/gBB, vitamin E 0,04 IU/gBB

Untuk mengetahui lebih lanjut perbedaan rerata tebal lapisan otot polos tuba fallopii, dilakukan uji lanjut post hoc test dengan menggunakan uji LSD ( Tabel 2).

Tabel 2. Hasil uji LSD tebal otot polos

\begin{tabular}{lccccc}
\hline p-value & $\mathrm{K}(-)$ & $\mathrm{K}(+)$ & PI & PII & PIII \\
\hline $\mathrm{K}(-)$ & & $0,039^{*}$ & 0,635 & 0,814 & $0,278^{*}$ \\
$\mathrm{~K}(+)$ & & 0,099 & $0,024^{*}$ & $0,003^{*}$ \\
$\mathrm{PI}$ & & & 0,480 & 0,126 \\
$\mathrm{PII}$ & & & & 0,391 \\
PIII & & & & \\
\hline
\end{tabular}

$p$-value $<0,05$ adalah bermakna $(*)$

\section{Pengaruh Kombinasi Dosis Vitamin C dan E}

Proses pengujian pengaruh kombinasi vitamin $\mathrm{C}$ dan $\mathrm{E}$ terhadap jumlah sel epitel sekretorik dan tebal lapisan otot polos tuba fallopii dilakukan dengan analisis regresi. Koefisien regresi pada persamaan regresi sebesar 45,703 menunjukkan bahwa dengan peningkatan pemberian kombinasi vitamin $\mathrm{C}$ dan $\mathrm{E}$ sebesar $0,1 \mathrm{mg} / \mathrm{gBB}$ tikus mampu meningkatkan jumlah sel epitel sekretorik sebesar 4,57 sel. Pada tebal lapisan otot polos nilai persamaan regresi sebesar 81,549 yang dapat diartikan bahwa dengan peningkatan pemberian kombinasi vitamin C dan E sebesar $0,1 \mathrm{mg} / \mathrm{gBB}$ tikus mampu meningkatkan tebal lapisan otot polos tuba fallopii sebesar 8,15 $\mu \mathrm{m}$.

Tabel 3. Hasil analisis korelasi dan regresi

\begin{tabular}{lccc}
\hline \multicolumn{1}{c}{ Variabel Terikat } & Persamaan Regresi & $\begin{array}{c}\text { Korelasi dan } \\
\mathbf{p} \text {-value }\end{array}$ & R-Square \\
\hline Jumlah Sel Epitel & $Y=55,264+45,703 X$ & $r=0,676 p=0,001$ & $45,73 \%$ \\
Sekretorik & & & \\
\hline
\end{tabular}


Tabel 3. Hasil Analisis Korelasi dan Regresi (Lanjutan)

\begin{tabular}{lccc}
\hline \multicolumn{1}{c}{ Variabel Terikat } & Persamaan Regresi & $\begin{array}{c}\text { Korelasi dan } \\
\text { p-value }\end{array}$ & R-Square \\
\hline Tebal Lapisan Otot & $Y=271,748+81,549 X$ & $r=0,663 p=0,001$ & $43,97 \%$ \\
Polos & & \\
\hline
\end{tabular}

\section{DISKUSI}

Pada penelitian ini, kelompok perlakuan yang mendapat MSG didapatkan efek jumlah sel epitel sekretorik dan penipisan pada lapisan otot polos tuba fallopii tikus. Diduga hal ini terjadi karena pemberian MSG yang berlebih dapat mempengaruhi mekanisme kerja hipotalamus sehingga kadar GnRH FSH dan LH menjadi turun. Hal ini akan berakibat pada ketidakseimbangan kadar hormon estrogen dan progesteron yang sangat berperan dalam siklus reproduksi. Beberapa penelitian telah dilakukan sebelumnya, menunjukkan pada tikus betina dewasa yang diberi MSG 0,04mg/ $\mathrm{kg}$ BB dan 0,08 $\mathrm{mg} / \mathrm{kg}$ BB selama 40 hari menyebabkan hipertrofi sel epitel, lisis pembuluh darah pada lapisan muskuler tuba fallopii, hal ini dikarenakan MSG direspon sebagai suatu toxic oleh tubuh yang menyebabkan terjadinya lisis dan nekrotik pada sel epitel tuba (5).

Sel epitel sekretorik berperan secara maksimal saat ovulasi untuk memungkinkan terjadinya konsepsi yang sangat bergantung pada kadar estrogen. Estrogen akan disekresi dengan baik jika umpan balik terhadap hipotalamus tidak terganggu oleh ROS. Sel epitel tergantung pada kadar estrogen, kadarnya akan meningkat menjelang pra-ovulasi, pada saat itulah ukuran sel epitel bersilia dan sekretorik dalam ukuran yang sama (6). Hal ini sejalan dengan penelitian lainnya yang menyatakan bahwa sel epitel sekretorik tuba berisi cairan nutritif yang banyak mengandung mukoproteins, elektrolit dan enzim yang diduga berasal dari transudasi selektif darah dan sekresi aktif dari lapisan epitel, cairan tersebut akan meningkat pada saat fase proestrus (7). Berkurangnya jumlah sel epitel sekretorik tuba fallopii akan menyebabkan radang panggul yang dihubungkan dengan kejadian infertilitas pada wanita, maka dengan memberikan antioksidan vitamin C dan E diharapkan mampu untuk mengurangi radikal bebas yang disebabkan oleh glutamat dan asam amino dalam konsentrasi tinggi pada fase sekresi dapat bermanfaat untuk embrio karena banyak mengandung cairan nutritif. Jika dihubungkan dengan MSG sebagai salah satu jenis asam amino penyusun protein, maka jika konsentrasi glutamat pada tubuh berubah menjadi radikal dan stress oksidatif, sel

\section{DAFTAR PUSTAKA}

1. Jinap S and Hajeb P. Glutamate Its Applications in Food and Contribution to Health. Faculty of Food Science and Technology. Appetite. 2010; 55: 1-10.

2. Camihort G, Gomez DC, Luna G, et al. Relationship Between Pituitary and Adipose Tissue after Hypothalamic Denervation in the Female Rat. Neuroendocrinology. 2005; 179(4): 192-201.

3. Megawati D, Sutarno, dan Listyawati S. Siklus Estrus Dan Struktur Histologis Ovarium Tikus Putih Setelah Pemberian MSG Secara Oral. Bio Smart. 2005; 7 (1): epitel sekretorik juga tidak akan disekresikan dengan maksimal, karena reseptor glutamat yang ada di sistem reproduksi akan berpengaruh pada signaling hormon gonad (12).

Sekresi tuba fallopii berupa cairan kompleks yang berasal dari sel epitel dan plasma darah, cairan tersebut mengandung banyak komponen metabolik yaitu glukosa, laktat, piruvat dan asam amino dalam konsentrasi yang berbeda-beda pada masing-masing orang (13). Cairan tersebut sangat berguna untuk perkembangan embrio, pada saat fase sekresi dari siklus estrus, sel epitel tuba fallopii melepaskan beberapa biomolekul kedalam lumen untuk meningkatkan perkembangan embrio yang diatur oleh hormon steroid oleh sel-sel gamet.

Lapisan muskularis tuba fallopii terdiri dari dua lapisan otot polos yaitu lapisan sirkuler bagian dalam dan lapisan longitudinal bagian luar, kontraksi otot polos akan menghasilkan gerakan peristaltik yang berfungsi untuk membantu perpindahan ovum menuju rahim. Hormon estrogen dapat merangsang motilitas tuba dan sebaliknya progesteron menghambat gerakan peristaltik tersebut (7).

Sel epitel bersilia, sel epitel sekretorik dan lapisan otot polos dianggap sebagai efektor mekanik transportasi tuba fallopii, pada otot polos ternyata ada reseptor estradiol dan progesteron yang berfungsi untuk kontraksi dan relaksasi otot polos (14). Otot polos tuba dibawah kendali sistem saraf simpatis, otot tuba merespon estrogen untuk menstimulasi kontraksi otot dan progesteron dan berefek relaksasi (15).

Dengan demikian, pemberian kombinasi vitamin $\mathrm{C}$ dan vitamin $\mathrm{E}$ berbagai dosis telah mampu untuk menangkal radikal Hidroksil $(\mathrm{OH})$ pada tuba fallopii dengan hasil meningkatkan jumlah sel epitel sekretorik dan tebal lapisan otot polos. Jumlah sel epitel sekretorik yang cukup akan menjadikan embrio dapat bertahan di tuba saat terjadinya konsepsi karena sel sekretorik mengandung cairan nutritif untuk embrio, sedangkan pada lapisan otot polos akan menciptakan gerakan peristaltik untuk mengantarkan embrio ke kavum uteri, keduanya dipengaruhi oleh kadar estrogen yang dihasilkan oleh ovarium terhadap FSH dan LH yang disekresikan oleh hipofise anterior.

Kombinasi vitamin C dan vitamin E berpengaruh terhadap peningkatan jumlah sel epitel sekretorik dan tebal lapisan otot polos tuba fallopii tikus yang dipapar MSG. Semakin tinggi kombinasi dosis vitamin $C$ dan vitamin $E$ semakin memberikan efek yang lebih besar pada peningkatan jumlah sel epitel sekretorik dan tebal lapisan otot polos tuba fallopii tikus yang dipapar MSG.

\section{7-52.}

4. Gupta S, Sekhon L, Aziz N, and Agarwal A. The Impact of Oxidative Stress on Female Reproduction and Art: An Evidence-Based Review. Infertility and Assited Reproduction. 2008; 64: 178-186.

5. Eweka OS, Eweka A, and Iniabobs FAE. Histological Studies of the Effect of MSG of the Fallopian Tubes of Adult Female Wistar Rats. North American Journal of Medical Sciences. 2010; 2(3): 146-149.

6. Lyons AR, Saridogan E, and Djahanbakhch O. The Reproductive Significance of Human Fallopian Tube 
Cilia. Human Reproduction Updates. 2006; 12(4): 363-372.

7. El-Mowafi DM. Fallopian Tube. (Online) 2012. http://www.gfmer.ch/International_activities_En/EI _Mowafi/Fallopian_tube.htm

8. Muchsin R. Pengaruh Pemberian MSG Terhadap Histologi Endometrium Mencit. [Tesis]. Universitas Sumatera Utara, Medan. 2009.

9. Subandi, Widodo, dan Aurora H. Pengaruh Pemberian Kombinasi Vitamin E dan Vitamin C terhadap sel Radang di Septum Interaveolar Paru Tikus yang dipapar Asap Rokok Sub Kronis. [Skripsi]. Universitas Brawijaya, Malang. 2006.

10. Biesalski KH. Vitamin E Requirments in Parenteral Nutrition. Gastroenterology. 2009; 137(5): 92-104.

11. Hanafiah KA. Rancangan Percobaan Teori dan
Aplikasi. Edisi 3. Jakarta: PT Raja Gravindo Persada; 2012; hal. 9-10.

12. Tay JI, Rutherford AJ, Killick SR, Maguines SD, Patridge RJ, and Leese HJ. Human Tubal Fluid: Production, Nutrient Composition and Response to Adrenergic Agents. Human Reproduction. 1997; 12(11): 24512456.

13. Aviles M, Gutierrez AA, and Coy P. Oviductal Secretions: Will They be Key Factors for the Future ARTs? Molecular Human Reproduction. 2010; 16(12): 896-906.

14. Croxato HB. Physiology of Gamete and Embryo Transport Through the Fallopian Tube. Reproductive BioMedicine Online. 2002; 4(2): 160-169.

15. Talbot $P$ and Riveles K. Smoking and Reproduction: The Oviduct as a Target of Cigarette Smoke. Reproductive Biology and Endocrinology. 2005; 3: 52. 